\title{
The Possible Ameliorative Effect of Hesperidin Administration in Aluminum Phosphide Induced Acute Nephrotoxicity in Adult Albino Rats
}

\author{
Sahar Mohamed Moustafa, Rania Kamal Hashish, Rehab Ibrahim Abdel-Karim ${ }^{1}$ \\ ${ }^{1}$ Department of Forensic Medicine and Clinical Toxicology, Faculty of Medicine- Suez Canal University, Suez Egypt.
}

\begin{abstract}
Background: Aluminum phosphide (ALP) is considered as an inorganic phosphide used in controlling insects and rodents. Aluminum phosphide is highly toxic to human and animal and it can be lethal even in little amount, as it liberates a poisonous gas, phosphine under the moist conditions. Hesperidin (HSD) is a flavanone glycoside and is considered as an anti-inflammatory and antioxidant agent. Aim of the work: The present study aimed to explore the probable ameliorative effect of antioxidant hesperidin on aluminum phosphide-induced nephrotoxic changes in adult albino rats after acute exposure. Materials and methods: A thirty-six adult albino rats were divided into four groups as follows: Control group I, HSD-treated group (II): The rats received HSD (200 mg/kg b.w.). ALP-treated group (III): The rats received ALP (12 $\mathrm{mg} / \mathrm{kg}$ b.w.). HSD-therapeutic group (IV): The rats received HSD (200 mg/kg b.w.) after ALP administration. Serum protein, urea, creatinine, antioxidant enzymes (GST and SOD), renal GST, MDA, SOD and lipid peroxidation markers (TBARS), were analyzed. The histological changes in kidney were assessed by using both light and electron microscopes. Results: The results revealed that HSD therapy provided marked improvement against ALP-induced acute renal toxicity which appeared in biochemical, histological and proximal convoluted tubules changes which were assessed by light and electron microscopes. Conclusion: The study concluded that HSD has an ameliorative effect in ALP induced-nephrotoxicity in adult albino rats. It increases the hope of using HSD as a new effective antidote in ALP-induced toxicity and gives an opportunity for experimental and clinical trials to evaluate its role in ALP toxicity management.
\end{abstract}

Received in original form: 30 July 2021 Accepted in a final form: 7 Augest 2021

Key words Aluminum phosphide, Hesperidin, Nephrotoxicity, Albino rats

\section{Introduction}

A cute renal injury is a major public health problem and is considered as a major cause of morbidity and mortality (Hayek et al., 2020). Nephrotoxicity may result from a certain dosedependent mechanisms (Sales and Foresto, 2020). Aluminum phosphide (ALP) is considered as an inorganic phosphide which is used in controlling both rodents and insects as it is mainly used as indoor fumigant during crops' storage (O'Malley et al., 2013). It is available as tablets, pallets, sachets or dusts and known as tablet of rice. ALP is highly toxic to both human and animal, it can cause death even in a little amount, as it forms a highly poisonous gas, (phosphine) under the moist conditions (Dua and Gill, 2004). ALP is usually ingested in suicidal attempts while its occupational exposure is suspected (Moghadamnia, 2012). The exact renal toxic mechanism of ALP is undefined but oxidative stress is probable as it can inhibit the cytochrome-C oxidase activity along with the mitochondrial morphological chanags (Tahergorabi et al., 2020). Phosphine gas can form reactive hydroxyl radicals and reduce peroxidase, catalase and acetyl cholinesterase enzymes' function
(Nakhaee et al., 2017). Lipid peroxidation due to phosphine gas may be due to reactive oxygen species (ROS) which are generated as a result of inhibition of cellular respiration, and a reaction with $\mathrm{H}_{2} \mathrm{O}_{2}$ (Mokhtar et al., 2015). Hesperidin (HSD) is a flavanone glycoside which is found in citrus fruits and is considered as anti-inflammatory and antioxidant agent. It can decrease oxidative stress and production of proinflammatory cytokines in mice (Afra et al., 2019). It also can protect against chemical-induced hepatotoxicity and nephrotoxicity as it can protect cells from oxidative stress, as it is a powerful radical scavenger (Omar et al., 2016).

Hajialyani et al. (2019) documented that HSD has a neuroprotective effect as it ameliorates the neuronal growth factors as it is a potent antioxidant. The present study aimed to explore the probable antioxidant effect of hesperidin on aluminum phosphide-induced nephrotoxic changes in the kidney in adult albino rats after acute toxic exposure. 


\section{Materials and Methods}

Thirty-six adult male albino rats weighing 200$250 \mathrm{~g}$, aged 8 weeks were used. Animals were fed ad libitum and water and exposed to $12-\mathrm{hr}$ light and 12-hr dark cycle, at $25 \pm 2{ }^{\circ} \mathrm{C}$. Prior to be utilized for experimental purpose, rats were left for two weeks to acclimatize them to the new environment.

Drugs: Aluminum phosphide which was used in the experiment, was in the form of $3 \mathrm{gm}$ tablet (Excel crop care Ltd, India). HSD used was in the powder form of purity $\geq 97.0 \%$ (Sigma-Aldrich- St. Louis, MO, USA). Chemicals and drugs used in the experiment were of a high analytical category and were freshly prepared before each step of the experiment.

Drugs' doses: ALP dose was calculated according to that the dose of one-tenth $\mathrm{LD}_{50}$ for ALP can produce a sub-lethal toxic effect in rats according to Afolabi et al. (2018). Dose of $15 \mathrm{mg} / \mathrm{kg} \mathrm{b.w.} \mathrm{of} \mathrm{ALP} \mathrm{resulted} \mathrm{in}$ $100 \%$ mortality, and $8 \mathrm{mg} / \mathrm{kg}$ was resulted in $0 \%$ mortality thus, dose ranging between 8 and $15 \mathrm{mg} / \mathrm{kg}$ b.w. was applicable for acute toxicity with accepted mortality rate (Baeeri et al., 2013). The ALP $\mathrm{LD}_{50}$ in rats equal $8.7-15 \mathrm{mg} / \mathrm{kg}$ b.w. and $\mathrm{LD}_{100}$ equal 20 $\mathrm{mg} / \mathrm{kg}$, so the range of $8.7-20 \mathrm{mg} / \mathrm{kg} \mathrm{b.w}$. of ALP dissolved in corn oil can mimic real-life acute toxicity with a single dose (Anand et al., 2012). HSD dose was based on its antioxidant capacity (Arafa et al., 2009 and Ahmad et al., 2012). Survival time was monitored regularly by direct observation of rats in all groups for the first $6 \mathrm{~h}$. after that, they were checked for survival every $6 \mathrm{~h}$ for more than $48 \mathrm{~h}$ and every day till the end of the experiment.

Experimental design: After the two weeks acclimatization period, the rats were divided into four groups consisting of nine rats each, as follows: Group I (control group): The rats were further subdivided into: group Ia (negative control) where three rats did not receive any treatment, and group $\mathrm{Ib}$ (positive control): Three rats received $1 \mathrm{ml} / \mathrm{kg}$ body weight (b.w.) of corn oil through gavage, and group Ic: three rats were administrated $1 \mathrm{ml} / \mathrm{kg}$ b.w. saline (Richter et al., 2007). HSD-treated group (II): The rats received HSD (200 $\mathrm{mg} / \mathrm{kg} \mathrm{b}$.w. dissolved in saline) orally daily (Ahmad et al., 2012). ALP-treated group (III): The rats received ALP in a single oral dose of $(12 \mathrm{mg} / \mathrm{kg}$ b.w. dissolved in $1 \mathrm{ml}$ of corn oil) according to Bingham et al. (2001). HSD-therapeutic group (IV): The rats received HSD (200 mg/kg b.w.) dissolved in saline orally two hours after ALP administration with the same dose as in group II in the first day and daily after that (Arafa et al., 2009 and Anwer et al., 2014). At the end of the experiment (after 7 days), the rats were sacrificed after they were anesthetized by ketalar $50 \mathrm{mg} / \mathrm{kg}$ i.p. The blood samples were collected for the biochemical study and kidney tissues were dissected for the histopathological and ultrastructural studies.

Biochemical analysis: Blood samples were collected, heparinized and centrifuged at $860 \mathrm{x} . \mathrm{g}$. for $20 \mathrm{~min}$ for serum separation and stored at $-60^{\circ} \mathrm{C}$. Determination of serum urea was estimated according to Kaplan (1984) and creatinine according to Murray (1997) using test kits (Egyptian Company for Laboratory Services, Egypt). Plasma protein level was estimated according to Okutucu et al. (2007) using an auto analyzer (RocheHitachi, Japan) (Sembulingam and Sembulingam 2010). Stored plasma samples were analyzed for the activities of antioxidant enzymes as glutathione Stransferase (GST) according to Habig et al. (1974) and superoxide dismutase (SOD) according to Mishra and Fridovich (1972). Kidney tissues were washed by solution of ice-cold $0.9 \% \mathrm{NaCl}$ and homogenized in 9\% ice-cold phosphate-buffered saline with $\mathrm{PH}$ 7.5. The homogenate had been centrifuged at 3000 r.p.m for about $15 \mathrm{~min}$ and the supernatant was kept at $-80^{\circ} \mathrm{C}$. The resultant supernatant was used for assay of tissue oxidative stress markers of lipid peroxidation [thiobarbituric acid-reactive substances (TBARS) as lipid peroxidation index], renal GST and enzymes activities of Malondialdehyde (MDA) and SOD according to Beulter et al. (1963) and Luck (1972).

Histo-pathological examination: Kidneys were collected, washed with ice-cold saline, rinsed in a phosphate buffer and fixed in $10 \%$ buffered formalin. They were processed and prepared for paraffin embedded blocks and each block $5 \mu \mathrm{m}$ thick section were bisected sagittal and specimens were fixed in the suitable fixative according to the type of staining and prepared for histopathological study by light microscopy. The sections were embedded in paraffin wax and stained with hematoxylin and eosin (H\&E) stain and Periodic Acid-Schiff (PAS) for histopathological examination according to Halliwell and Chirico (1993). The cortex was cut into small pieces $1 \times 1 \mathrm{~mm}^{3}$ in size and fixed in $3 \%$ phosphate buffered glutaraldehyde and post-fixed in osmium tetroxide for ultrastructural electron microscopy examination using JOEL 100 CX (Glauret, 1986).

Ethical considerations: Approval of research Ethics Committee to the experimental design was obtained, the experimental procedures and animal maintenance were conducted in accordance with the accepted standards of animal care. Animals were handled only by the investigator and maintained in manners that provide their physical comfort. There was no interference except after complete anesthesia and at the time of sacrifice. The rats were anesthetized with ketalar.

Statistical analysis: All values were presented as mean \pm SD. The differences among the groups with respect to all measured data parameters were statistically analyzed using one-way analysis of variance (ANOVA) and the post-hoc test using SSPS program, version 17 (IBM Corporation, Somers, New York, USA). t-test was used to test the association between qualitative variables. The calculations were considered statistically significant if $\mathrm{P}$ value was less than 0.05 .

\section{Results}

The survival time: Mean survival time was (72 $\pm 7.6 \mathrm{~h}$.) after aluminum phosphide intoxication in group III. The time increased to $(147 \pm 6.8 \mathrm{~h}$.) in HSD- 
therapeutic group IV and it was highly significant (Table 1).

Biochemical parameters results: The results revealed a significant increase in serum urea and creatinine level and a significant decrease in serum protein in ALP treated group in comparison to both control and HSD-treated groups. A significant improvement in serum urea, creatinine and protein levels in HSD-therapeutic group in comparison to ALP-treated group was detected (Table 2).

Oxidative enzymes activity results: The results revealed a significant decrease in plasma GST level and SOD activity in ALP-treated group in comparison to both control and HSD-treated groups. A significant improvement in both SOD and GST levels in HSDtherapeutic group in comparison to ALP-treated group was detected (Table 3).

Results of lipid peroxidation index level and renal tissues oxidation enzymes activity: The results revealed a significant increase in tissue MDA and TBARS levels along with a significant decrease in GST and SOD activity in ALP-treated group in comparison to both control and HSD-treated groups. A significant improvement in renal MDA, SOD, GST and TBARS levels in HSD-therapeutic group in comparison to ALPtreated group was detected (Table 4).

Renal Histo-Pathological changes results: H\&Estained sections of control group showed, the normal renal corpuscles which surrounded by both proximal and distal convoluted tubules. Each corpuscle was formed from tuft of blood capillaries (the glomerulus) which were surrounded by the Bowman's capsule lined by a single layer of flat epithelium. Pyramidal cells lined each proximal convoluted tubule and the nuclei were round and apical. The distal convoluted tubules were lined with large number of cuboids epithelial cells. The lumens of the distal tubules were wider than the proximal tubules (Figure 1). PAS-stained sections showed the proximal convoluted tubules with bright red color basement membrane and deeply stained brush border. The distal convoluted tubules showed stained basement membrane but less bright than the proximal tubules (Figure 9).

The HSD-treated sections showed normal architecture, as the glomerulus showed a number of normal capillary loops with narrow lumina which lined with epithelial cells with rounded nuclei and no cellular infiltration (Figure 2).

The ALP-intoxicated sections, showed mild sub-capsular edema, vacuolar degeneration and cloudy swelling of renal tubules and collecting ducts (Figure 3). Shrunken glomeruli with relative widening of Bowman's capsule and severe hemorrhage were showed (Figure 4). Proximal convoluted tubules destruction of the epithelial lining cells and loss of brush border were illustrated (Figure 5) along with variable degrees of dilatation of the lumina and interstitial cellular infiltration (Figure 6), and the renal tubules suffered from cloudy swelling (Figure 7). In PAS-stained sections, the renal tubules showed a bright red colored basement membrane and deeply stained brush border. The glomeruli showed deeply stained basement membrane of the capillary loops (Figure 10).

The HSD-therapeutic sections showed restoring of the glomerular architecture with re-appearance of a number of normal capillary loops and the proximal convoluted tubule showed narrow lumina which were lined with epithelial cells and rounded nuclei (Figure 8). Sections showed proliferation of glomerular tuft and renal tubules were seen without any retrogressive changes and disappearance of PAS positive mesangial matrix in the renal glomeruli (Figure 11)

Renal ultrastructural examination by electron microscope: The ultrastructural examination of the proximal convoluted tubules (PCTs) of the control group revealed normal epithelial lining cells. The cells showed a central spherical euchromatic nucleus with prominent nucleolus, rough endoplasmic reticulum and normal mitochondria were seen. The apical portion of the cells showed microvilli forming the normal brush border of the PCTs (Figure 12). Examination of PCTs of HSDtreated group sections showed normal euchromatic nucleus with prominent nucleoli. The cytoplasm showed mitochondria, ribosome and rough endoplasmic reticulum with intact microvillous border (Figure 13). Examination of PCTs of ALP-treated sections showed, peripheral nuclear chromatin margination and nucleolar margination. The cytoplasm appeared with aggregated mitochondria, excessive basal vacuolations with increased endocytic vesicles (Figure 14). Shrunken nuclei with chromatin condensation along with cytoplasmic vacuoles, lipid droplets and microvillous border were also illustrated (Figure 15). Examination of PCTs of HSD-therapeutic group sections showed, near normal PCTs with spherical euchromatic nucleus with normal chromatin pattern. Intact microvillous border with junctional complex were seen. Cytoplasm with normal mitochondria, rough endoplasmic reticulum and ribosomes was illustrated (Figure 16).

Table (1): Comparison between the survival time in ALP-treated and HSD-therapeutic groups using t-test

\begin{tabular}{|c|c|c|c|}
\hline Groups & ALP-treated group & HSD-therapeutic group & P-value \\
\hline $\begin{array}{c}\text { Survival time in hours } \\
\text { Mean } \pm \text { SD }\end{array}$ & $72 \pm 7.6$ & $147 \pm 6.8$ & $<0.001$ \\
\hline
\end{tabular}

SD: Standard Deviation, ALP-treated group: (12 mg/kg b.w.), HSD-therapeutic group: (ALP $12 \mathrm{mg} / \mathrm{kg}$ b.w. plus HSD $200 \mathrm{mg} / \mathrm{kg}$ b.w.) 
Table 2: The effect of ALP, HSD and their combination on serum urea, creatinine and protein level in rats by using one-way ANOVA test

\begin{tabular}{|c|c|c|c|c|c|}
\hline $\begin{array}{c}\text { Parameter } \\
\text { Mean } \pm \text { SD }\end{array}$ & Group I & Group II & Group III & Group IV & P-value \\
\hline Urea $(\mathbf{m g} / \mathbf{d l})$ & $37 \pm 0.7$ & $37.5 \pm 5.3$ & $90.6 \pm 8.8^{{ }^{*}, \mathrm{~b}}$ & $44.7 \pm 3.6^{*_{\mathrm{a}, \mathrm{b}, \mathrm{b}}}$ & $<0.05$ \\
\hline Creatinine $(\mathbf{m g} / \mathbf{d l})$ & $0.45 \pm 0.02$ & $0.46 \pm 60.06$ & $1.4 \pm 0.08^{*_{\mathrm{a}, \mathrm{b}}}$ & $0.55 \pm 0.04^{\mathrm{a}, \mathrm{b}, \mathrm{c}}$ & $<0.05$ \\
\hline Protein $(\mathbf{m g} / \mathbf{d l})$ & $8.49 \pm 0.18$ & $8.39 \pm 0.19$ & $7.39 \pm 0.12^{*, \mathrm{a}, \mathrm{b}}$ & $8.1 \pm 0.37^{*_{\mathrm{c}}}$ & $<0.05$ \\
\hline
\end{tabular}

Each group consists of 9 rats

Group I: Control group. Group II: HSD-treated group (200 mg/kg b.w.)

Group III: ALP-treated group (12 $\mathrm{mg} / \mathrm{kg}$ b.w.)

Group IV: HSD-therapeutic group (ALP $12 \mathrm{mg} / \mathrm{kg}$ b.w. plus HSD $200 \mathrm{mg} / \mathrm{kg} \mathrm{b.w.)}$

$S D$ : Standard Deviation, * $P<0.05$ significant

a compared to control group.

${ }^{b}$ compared to HSD-treated group.

${ }^{c}$ compared to ALP-treated group.

Table 3: The effect of ALP, HSD and their combination on serum GST and SOD levels in rats by using one-way ANOVA test

\begin{tabular}{|c|c|c|c|c|c|}
\hline $\begin{array}{c}\text { Parameter } \\
\text { Mean } \pm \text { SD }\end{array}$ & Group I & Group II & Group III & Group IV & P-value \\
\hline GST $(\boldsymbol{\mu m o l} / \mathbf{h r} / \mathbf{m l})$ & $1.0 \pm 1.03$ & $0.98 \pm 0.03$ & $0.8 \pm 0.02^{* a, b}$ & $0.97 \pm 0.02^{{ }^{*} \mathrm{c}}$ & $<0.05$ \\
\hline SOD $(\mathbf{U} / \mathbf{m l})$ & $0.84 \pm 0.03$ & $0.82 \pm 0.05$ & $0.54 \pm 0.04^{* a, b}$ & $0.81 \pm 0.01^{{ }^{*} \mathrm{c}}$ & $<0.05$ \\
\hline
\end{tabular}

Each group consists of 9 rats

GST: (Plasma glutathione S-transferase), SOD: (Superoxide dismutase)

Group I: Control group. Group II: HSD-treated group (200 mg/kg b.w.)

Group III: ALP-treated group (12 $\mathrm{mg} / \mathrm{kg}$ b.w.)

Group IV: HSD-therapeutic group (ALP $12 \mathrm{mg} / \mathrm{kg}$ b.w. plus HSD $200 \mathrm{mg} / \mathrm{kg}$ b.w.)

SD: Standard Deviation, * $P<0.05$ significant

${ }^{a}$ compared to control group.

${ }^{b}$ compared to HSD-treated group.

${ }^{c}$ compared to ALP-treated group.

Table 4: The effect of ALP, HSD and their combination on GST, MDA, SOD and TBARS renal tissues levels in rats by using one-way ANOVA test

\begin{tabular}{|c|c|c|c|c|c|}
\hline $\begin{array}{c}\text { Parameter } \\
\text { Mean } \pm \text { SD }\end{array}$ & Group I & Group II & Group III & Group IV & P-value \\
\hline $\begin{array}{c}\text { GST } \\
\text { (nmol/g protein) }\end{array}$ & $16.3 \pm 1.4$ & $15.9 \pm 0.77$ & $6.1 \pm 0.32^{*_{\mathrm{a}, \mathrm{b}}}$ & $15.2 \pm 0.12^{*_{\mathrm{c}}}$ & $<0.05$ \\
\hline $\begin{array}{c}\text { MDA } \\
\text { (nmol/g protein) }\end{array}$ & $0.76 \pm 0.07$ & $0.78 \pm 0.16$ & $3.74 \pm 0.23^{*_{\mathrm{a}, \mathrm{b}}}$ & $0.82 \pm 0.08^{{ }^{{ }^{\mathrm{c}}}}$ & $<0.05$ \\
\hline $\begin{array}{c}\text { SOD } \\
\text { (U/mg protein) }\end{array}$ & $1.14 \pm 0.3$ & $1.09 \pm 0.4$ & $0.64 \pm 0.4^{*_{\mathrm{a}, \mathrm{b}}}$ & $1.09 \pm 0.31^{{ }^{*} \mathrm{c}}$ & $<0.05$ \\
\hline $\begin{array}{c}\text { TBARS } \\
\text { (nmol/g tissue) }\end{array}$ & $17.3 \pm 0.77$ & $17.3 \pm 0.05$ & $20.8 \pm 0.51^{*_{\mathrm{a}, \mathrm{b}}}$ & $17.2 \pm 0.05^{{ }^{*} \mathrm{c}}$ & $<0.05$ \\
\hline
\end{tabular}

Each group consists of 9 rats

GST: (Renal tissue glutathione S-transferase), MDA: (Malondialdehyde)

SOD: (Superoxide dismutase), TBARS: (Thiobarbituric acid-reactive substances)

Group I: Control group. Group II: HSD-treated group (200 mg/kg b.w.)

Group III: ALP-treated group (12 $\mathrm{mg} / \mathrm{kg} \mathrm{b.w.)}$

Group IV: HSD-therapeutic group (ALP $12 \mathrm{mg} / \mathrm{kg}$ b.w. plus HSD $200 \mathrm{mg} / \mathrm{kg}$ b.w.)

SD: Standard Deviation, $* P<0.05$ significant

a compared to control group.

${ }^{b}$ compared to HSD-treated group.

${ }^{c}$ compared to ALP-treated group. 


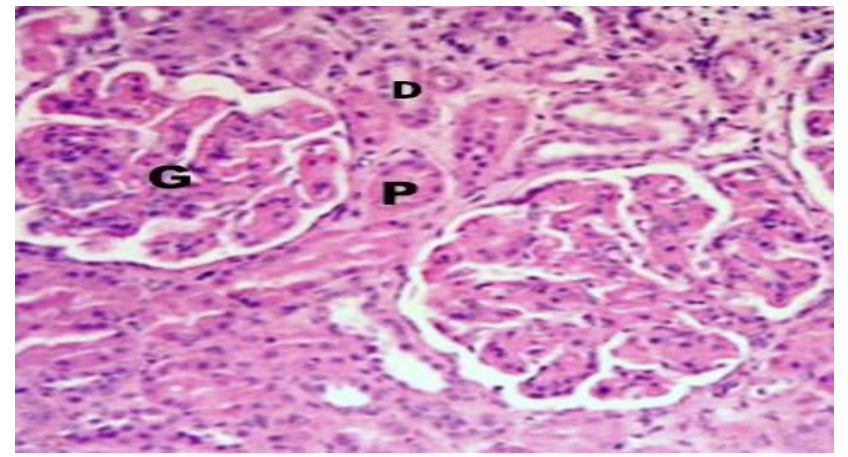

Figure (1): A photomicrograph of kidney section in control group, showing normal architecture. The glomerulus shows a number of capillary loops (G) and the proximal convoluted tubule $(P)$ shows narrow lumina lined with epithelial cells with rounded nuclei. The distal convoluted tubule (D) was lined by a large number of cuboidal epithelial cells and its lumen is wider than the proximal tubule (H\&E X 500).

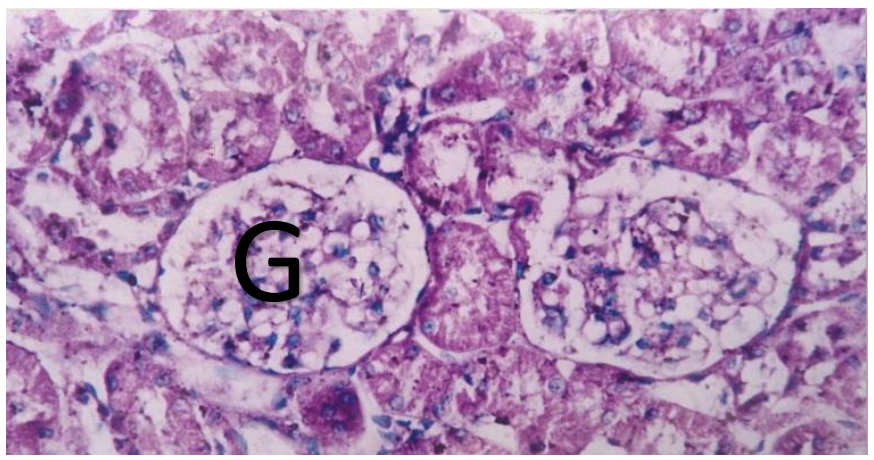

Figure (2): A photomicrograph of HSD-treated section, showing the normal architecture. The glomerulus (G) shows a number of capillary loops with narrow lumina which were lined with epithelial cells with rounded nuclei and no cellular infiltration (H\&E X 400).

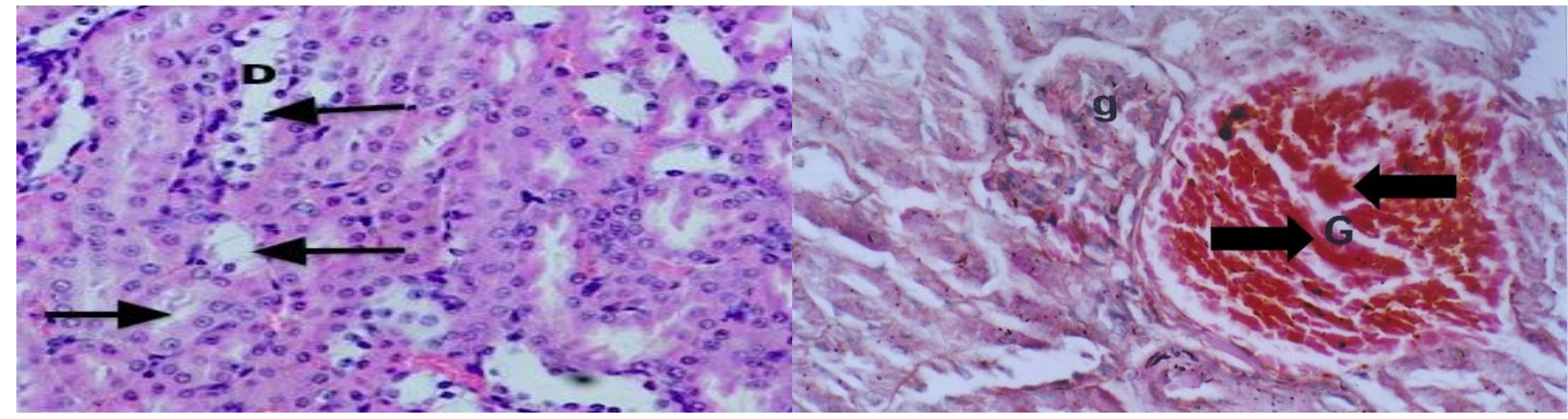

Figure (3): Photomicrograph of ALP-intoxicated section, showing mild vacuolar degeneration within the distal convoluted tubules (black arrows) (H\&E X 200).
Figure (4): A photomicrograph of ALP-intoxicated section, showing shrunken glomeruli $(G)$ with relative widening of bowman's capsule with severe hemorrhage (black arrows) (H\&E X 400).

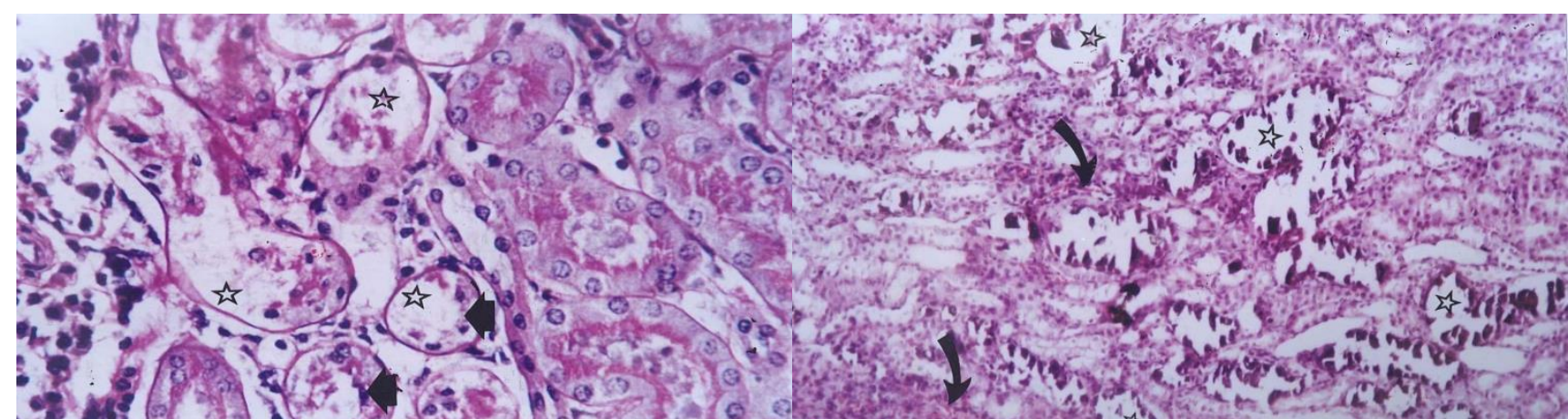

Figure (5): A photomicrograph of ALP-intoxicated section, showing proximal convoluted tubules with destruction of the epithelial lining cells (black stars) and loss of brush border (black arrow heads) (H\&E X 500).
Figure (6): A photomicrograph of ALP-intoxicated section, showing variable degrees of dilatation of the lumina (black stars) and interstitial cellular infiltration (black arrows) (H\&E X 200). 

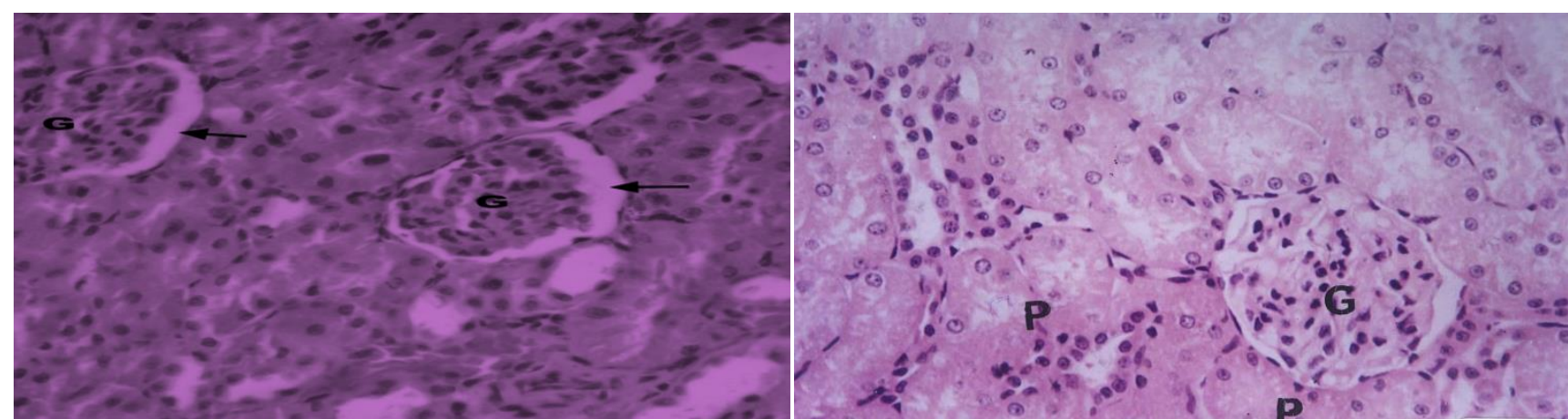

Figure (7): Photomicrograph of ALP-treated section, showing periglomerular cloudy edema (black arrows) (H\&E X 400).

Figure (8): A photomicrograph of HSD-therapeutic section, showing restoring the architecture. The glomerulus shows a number of capillary loops (G) and proximal convoluted tubule $(P)$ with narrow lumina which were lined with epithelial cells and rounded nuclei (H\&E X 400).

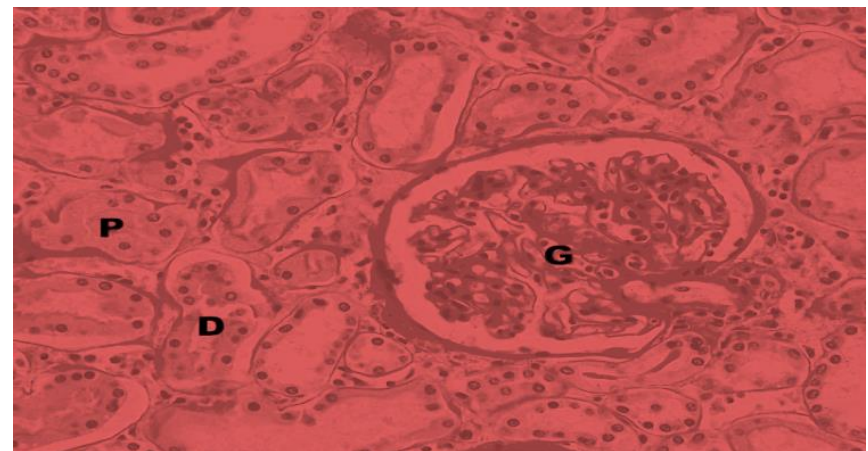

Figure (9): A photomicrograph of a section in the kidney of a control group showing PAS positive material in the brush border of the proximal tubules (P) and the basement membrane of the distal (D) renal tubules (PAS X 400).

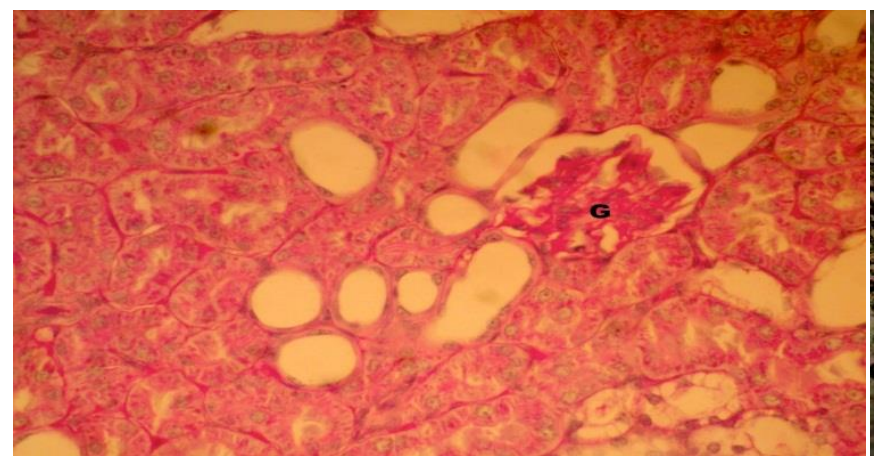

Figure (11): Photomicrograph of HSD-therapeutic section, showing glomerular tuft of capillary with PAS positive material in the brush border of the proximal tubules and the basement membrane of the renal tubules (PAS X 400).

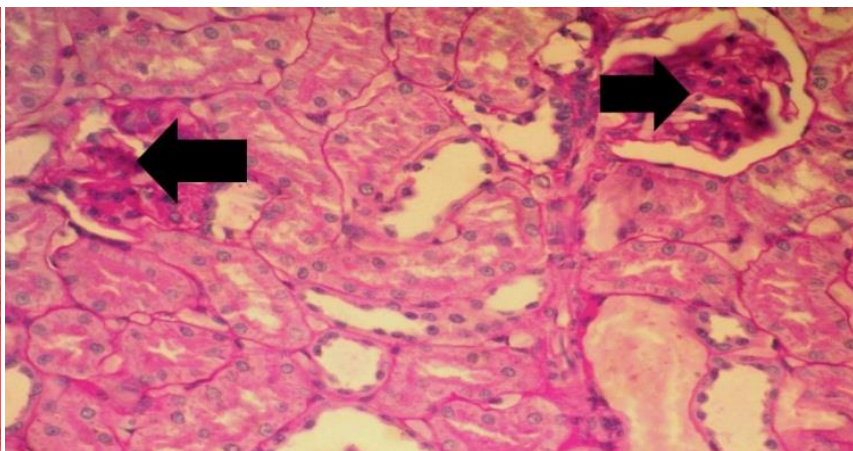

Figure (10): Photomicrograph of ALP-intoxicated section, showing massive increase in PAS positive stain in the brush border of the proximal and distal tubules and basement membrane of the renal tubules (black arrows) (PAS X 400).

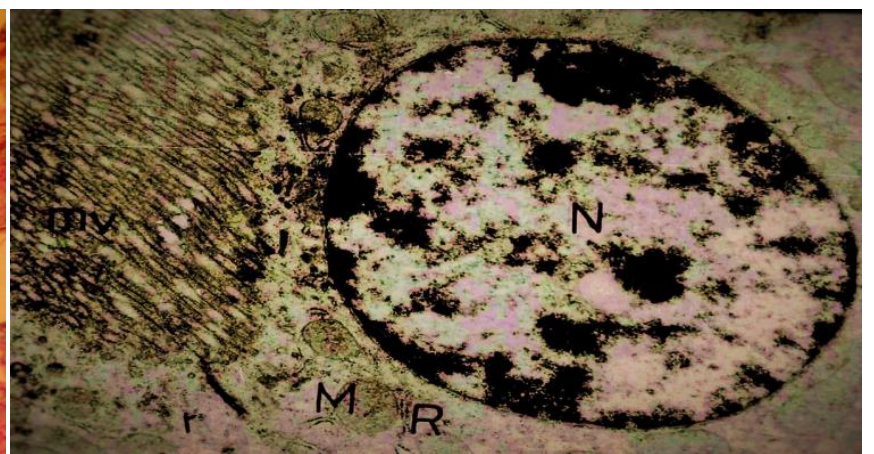

Figure (12): Electron photomicrographs of control section showing PCT cells with spherical euchromatic nucleus $(\mathbf{N})$. The cytoplasm contains mitochondria $(\mathbf{M})$, rough endoplasmic reticulum $(R)$, ribosomes (r) and prominent microvillous border (mv) (Mic. Mag: $X$ 6700). 


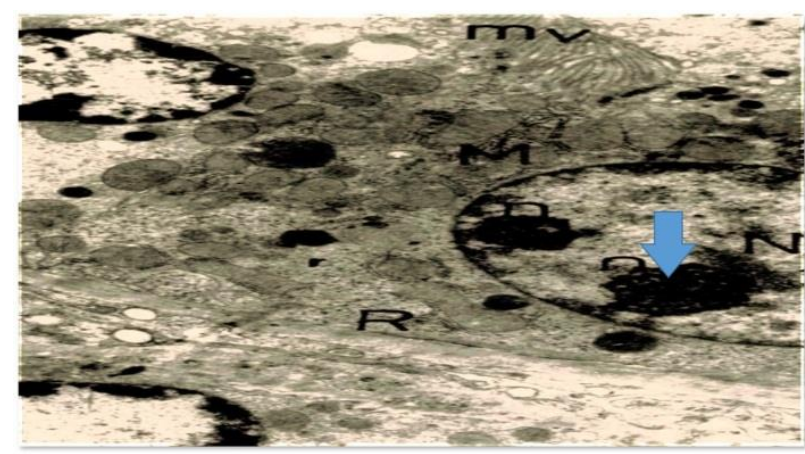

Figure (13): Electron photomicrographs of HSDtreated section showing, normal euchromatic nucleus with prominent nucleoli (n) (blue arrow). The cytoplasm shows mitochondria (M), ribosome $(r)$ and rough endoplasmic reticulum $(R)$ with intact microvillous border (mv) (Mic. Mag: X: 5000).

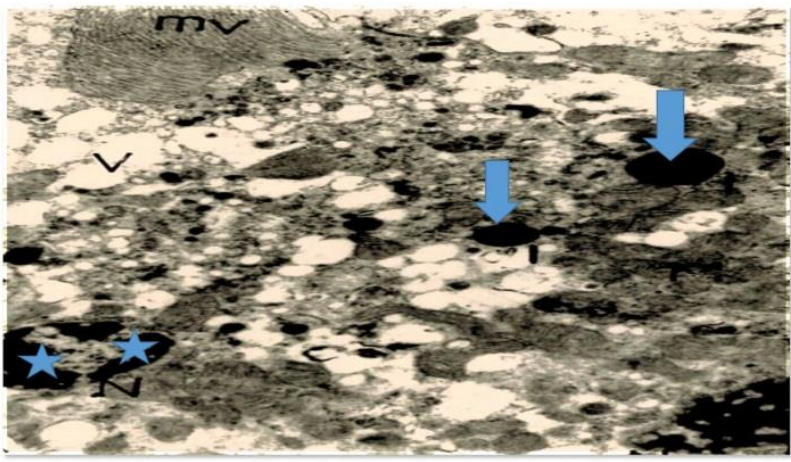

Figure (15): Electron photomicrographs of ALPintoxicated section showing, PCT with shrunken nuclei $(\mathbf{N})$ with chromatin condensation (blue stars). It shows cytoplasmic vacuoles (V), lipid droplets (I) (blue arrows) with microvillous border (mv) (Mic. Mag: X 5000).

\section{Discussion}

Natural antioxidant therapies became new field for oxidative stress and inflammation management. HSD is considered as natural antioxidant, which has many pharmacological effects (Küçükler et al., 2021). The current results revealed that, the survival time of the HSD-therapeutic group was increased in comparison to ALP-treated group. That result was in agreement with a study's results which documented that a survival time in ALP plus boric acid treated rats was much increased in comparison to ALP intoxicated group (Sweilum et al., 2017).

The current results revealed that ALP administration resulted in nephrotoxicity, which was reflected by significant elevations in serum urea, creatinine levels along with significant reduction in serum proteins, SOD and GST levels.

These results were in agreement with Chugh et al. (1997) results which stated that ALP administration leads to a low SOD activity that results in increase formation of free radicals and accelerate lipid peroxidation. Sudakin (2005) stated that kidney is one of the main targets of ALP poisoning as it can induce

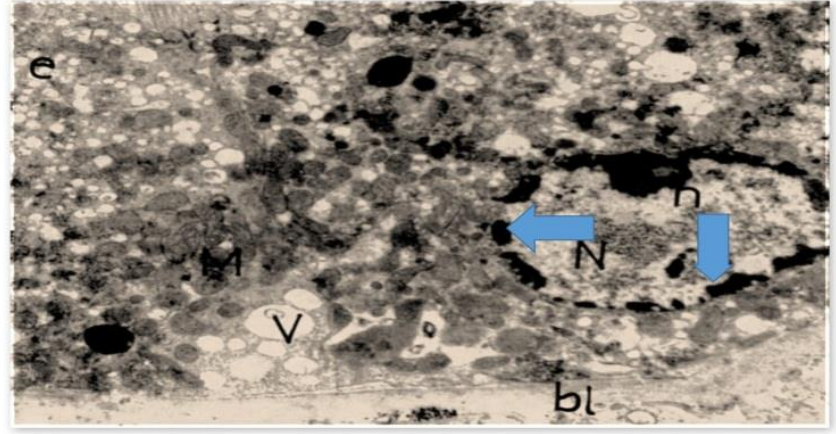

Figure (14): Electron photomicrographs of ALPintoxicated section showing, PCT resting on thickened basal lamina (bl). Nucleus (N) showing peripheral chromatin margination (blue arrows) and nucleolar margination (n). The cytoplasm shows aggregated mitochondria (M), excessive basal vacuolations $(\mathrm{V})$ and increased endocytic vesicles (e) (Mic. Mag: X 4000).

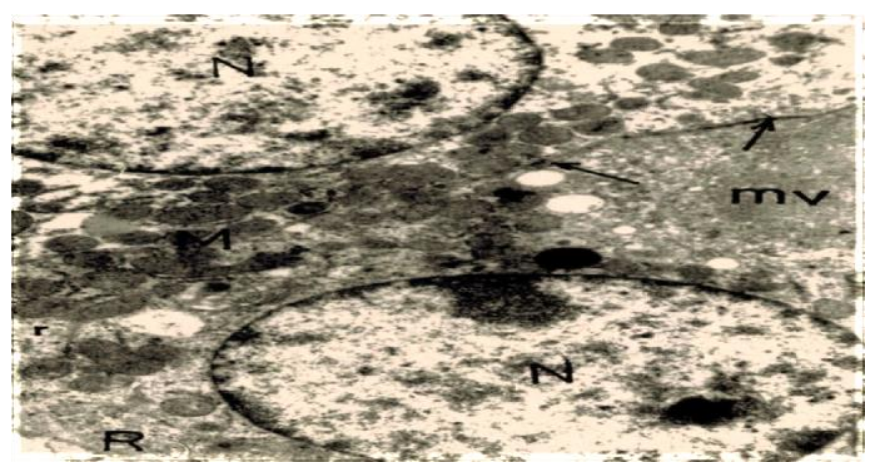

Figure (16): Electron photomicrographs of therapeuticHSD section, showing near normal PCT with spherical euchromatic nucleus $(N)$ with normal chromatin pattern. It shows intact microvillous border ( $\mathrm{mv}$ ) with junctional complex (black arrows). The cytoplasm shows normal mitochondria $(M)$, rough endoplasmic reticulum $(R)$ and ribosome (r) (Mic. Mag. X: 5000).

acute renal failure with increased serum urea and creatinine levels. ALP intoxication induces cellular superoxide and peroxide radicals, with subsequent cellular damage which caused by lipid peroxidation. Lipid peroxidation, and other oxidant mechanisms can damage the cellular membranes, ionic barrier and nucleic acid and lead to cellular death. (Kariman et al., 2012). Aluminum phosphide can also, trigger iron release from the protein storage, leading to massive cell injury (Cha'on et al., 2007). Oxidative stress is the result of increase in free radicals and reactive oxygen species (ROS).

Lipid peroxidation is a mechanism of cellular injury caused by ROS that damages the polyunsaturated lipids due to the generation of peroxides that metabolized to toxic products (Pompella et al., 2003). Free radicals can inhibit the cellular respiration and react with $\mathrm{H}_{2} \mathrm{O}_{2}$ and these are the basis of the genotoxicity in human and mice (Quistad et al., 2000). The oxidative stress changes were confirmed by an increase in renal MDA which is considered as an end-product of free radical chain reaction. GST is 
considered as an enzyme that has an important role in maintaining cellular homeostasis and in the detoxification of toxicants so, its decrease is considered as an indication of high oxidative stress (Abdel-Raheem and Abdel-Ghany 2009).

The current results stated reduced renal tissues' enzymes as GST, SOD with increased MDA and TABARS levels. Low GST level, might be resulted from its substrate lack along with the oxidative modification of its protein structure. SOD activity reduction leads to renal accumulation of the free radicals and ROS which are considered as potent oxidant as they induce oxidative damage in macromolecules, and its increased production may further aggravate the oxidative damage in rats while ROS can affect the glomerular filtration rate leading to elevation of renal profiles (Afolabi et al., 2018). MDA and TABARS levels are used for estimation of lipid peroxidation and oxidative membrane damage (Küçükler et al., 2021). Increased MDA and TABARS levels suggests that lipid peroxidation may be triggered by ALP. The alterations in the biochemical parameters are correlated with the renal histopathological changes. The current results documented the histopathological changes induced by ALP administration in rats were illustrated in the form of shrunken glomeruli with exhibiting hemorrhage, proximal convoluted tubules destruction along with vacuolar degeneration and brush border loss. The present results are in accordance with Hsu et al. (2002) results which stated a coagulative necrosis of the tubular epithelium in the outer cortex due to the oxidative stress related to ALP nephrotoxic effects. The current results are in contrast with Garrosa et al. (2011) results which documented that accumulation of ALP was restricted to the connective tissue surrounding the kidney with mild cortical atrophy and no renal changes.

The current study revealed tubular cell affections following ALP intoxication ranged from a cytoplasmic vacuolation, lipid droplets and organelles affections to nuclear lesions as illustrated by the electron microscope. Those changes may be due to interaction of ALP with phospholipid cell membrane and increase in reactive oxygen species with the consequent increase in lipid peroxidation (Mahboob et al., 2001). The mitochondrial aggregation, which appeared, may be a compensatory mechanism to the mitochondrial dysfunction, while the lipid droplets appearance may be due to the detoxifying effect of the smooth endoplasmic reticulum in the intoxicated renal tubules (Rodilla et al., 1998). The nuclear lesions found in ALP intoxicated sections were in the form of shrunken nuclei with chromatin condensation and nucleolar margination. Those changes are considered as morphologic changes specific to ALP-induced apoptosis (Goering et al., 1999).

The current results showed that HSD decreased the oxidative stress changes induced by ALP as HSD played a potent role in ameliorating the induced oxidative damage by increasing the antioxidant status in renal tissue. In the current study, HSD administration showed a significant decrease in serum urea and creatinine along with increased serum GST, SOD and protein levels. Furthermore, HSD administration also showed a decrease in renal tissues MDA and TBARS with increase in renal GST and SOD levels as compared to the ALP-intoxicated group. The present results are in accordance with Ganeshpurkar and Saluja (2019) results which documented that HSD provide antioxidant effect against drug-induced nephrotoxicity. Pari et al. (2015) documented that HSD can improve renal functions, renal antioxidant levels and decrease the iron concentration in blood. It is suggested that HSD is reported to ameliorate the decreased levels of the antioxidant enzymes as CAT and GST as it acts as a direct free radical scavenger for hydroxyl free radicals. Furthermore, a recent study stated that HSD is a potent antioxidant agent as it improved acetaminophen induced nephrotoxicity, and was superior to other antioxidants agents (Emam and Madboly 2021). Administration of HSD to rats can reduce the hydroxyl radicals and elevate the glutathione level. Thus, it can prevent the oxidation of reduced glutathione and protects its enzymes from peroxidative damage. Treatment of renal toxicity by mercuric chloride in rats with HSD enhanced GST and SOD activities in the renal tissue as HSD is considered as a strong antioxidant which can prevent renal oxidative damage (Bharathi and Jagadeesan 2014). The present results concluded that treatment with HSD ameliorated the histopathological changes induced due to ALP toxicity in kidney. Those results are in agreement with a study which documented that, the histopathological degenerative changes in renal tissue induced by cisplatin, and confirmed with the biochemical parameters of the oxidative stress, were ameliorated by HSD treatment (Kamel et al., 2014).

The current results documented absence of the ultrastructural changes in ALP plus HSD treated group. The current results agree with a study which revealed that HSD ameliorates trichloroethylene-induced nephrotoxicity as it has an antioxidant role in scavenging the free radicals and alteration of apoptotic pathway proteins caspase-3 as it is considered as a potent nephroprotective agent (Siddiqi et al., 2015). A recent study stated that HSD has a protective effect against chlorpyrifos-induced kidney damage as it is a potent natural antioxidant (Küçükler et al., 2021).

\section{Conclusion}

The study concluded that aluminum phosphide exposure induces free radicals and hazardous changes in some biochemical and enzymatic activities. HSD has an ameliorative effect in ALP-induced acute nephrotoxicity changes in adult albino rats, as it is a potent antioxidant. It increases the hope of using HSD as a new effective antidote for ALP acute toxicity, and gives an opportunity for the future experimental and clinical trials to evaluate its role in acute ALP toxicity management. 


\section{References}

Abdel-Raheem IT and Abdel-Ghany AA (2009): Hesperidin alleviates doxorubicin-induced cardiotoxicity in rats. J Egypt Natl Cancer Inst; 21:175.

Afolabi OK, Wusu AD, Ugbaja $R$ et al., (2018): Aluminum phosphide-induced testicular toxicity through oxidative stress in Wister rats: Ameliorative role of hesperidin. Toxicology research and applications. Vol. 12. 1-11.

Afra, HS, Zangooei M, Meshkani R et al., (2019): Hesperidin is a potent bioactivator that activates SIRT1AMPK signaling pathway in HepG2cells. Journal of physiology and biochemistry 75(2), 125-133.

Ahmad ST, Arjumand $W$ and Nafees S (2012): Hesperidin alleviates acetaminophen induced toxicity in Wistar rats by abrogation of oxidative stress, apoptosis and inflammation. Toxicol. Lett.; 208: 149-161.

Anand R, Kumari P, Kaushal A, et al., (2012): Effect of acute aluminum phosphide exposure on rats: a biochemical and histological correlation. Toxicol. Lett; 215:62-69.

Anwer MK, Al-Shdefat R, Jamil, S, et al., (2014): Solubility of bioactive compound hesperidin in six pure solvents at (298.15 to333.15) K. J. Chem. Eng. Data, 596: 2065-2069.

Arafa H, Aly H and Abd-Ellah M (2009): Hesperidin attenuates benzo pyrene-induced testicular toxicity in rats via regulation of oxidant/antioxidant balance. Toxicol. Ind. Health; 25: 417-427.

Baeeri M, Shariatpanahi M, Baghaei A, et al., (2013): On the benefit of magnetic magnesium nanocarrier in cardiovascular toxicity of aluminum phosphide. Toxicol Ind Health; 29:126-135.

Beulter E, Duron O and Kelly MB (1963): Improved method for the determination of blood glutathione. J Lab Clin Med; 61: 882-888.

Bharathi E and Jagadeesan G (2014): Antioxidant potential of hesperidin and ellagic acid on renal toxicity induced by mercuric chloride in rats. Biomedicine and preventive nutrition; 4(2): 131-136.

Bingham E, Cohrssen B and Powell CH (2001): Patty's toxicology. metals and metal compounds, compounds of inorganic nitrogen, carbon, oxygen and halogens. Hoboken: John Wiley and Sons. Vol. 3. 200202.

Cha'on U, Valmas N, Collins PJ, et al., (2007): Disruption of Iron homeostasis increases phosphine toxicity in Caenorhabditis elegans. Toxicol Sci; 96(1): 194-201.

Chugh SN, Kolley T, Kakkar R, et al., (1997): A critical evaluation of anti-per oxidant effect of intravenous magnesium in acute aluminum phosphide poisoning. Magnes Res; 10(3): 225-230.

Dua R and Gill KD (2004): Effect of aluminum phosphide exposure on kinetic properties of cytochrome oxidase and mitochondrial energy metabolism in rat brain, Biochim. Biophys. Acta; 1674, 4-11.

Emam HT and Madboly AG (2021): Ameliorative effects of hesperidin and melatonin against acetaminophen induced nephrotoxicity in adult albino rats. Egypt J. Forensic Sci. Appli. Toxicol. Vol 21 (1), 31-47.

Ganeshpurkar, A and Saluja, A (2019): The pharmacological potential of hesperidin. Ind. J. Biochem. Biophys., 56: 287-300.

Garrosa M, Llanes F and Gayoso MJ (2011): Histopathological changes in gerbil liver and kidney after aluminum sub-chronic intoxication. Histo 1 Histopathol; 26: 883-892.

Glauret, AM (1986): Fixation, dehydration and embedding of biological specimens. Practical methods in electron microscopy. $1^{\text {st }}$ ed. North Holland Publishing Company Amsterdam, New York, Oxford, 111-148.

Goering PI, Thomas D, Rojko JL, et al., (1999): Mercuric chloride induced apoptosis is dependent on protein synthesis. Toxicol. Lett.; 105(3): 183-195.

Habig WH, Pabst MJ and Jakoby WB (1974): Glutathione S-transferases. The first enzymatic step in mercapturic acid formation. J Biol Chem; 249:71307179.

Hajialyani M, Farzaei MH, Echeverria J, et al., (2019): Hesperidin as a neuroprotective agent: a review of animal and clinical evidence. Molecules. 24: 648.

Halliwell B and Chirico S (1993): Lipid peroxidation: its mechanism, measurement, and significance. Am. J. Clin. Nutr., 57: 715-724.

Hayek SS, Leaf DE, Tahhan AS, et al., (2020): Soluble urokinase receptor and acute kidney injury. N. Engl. J. Med., 382: 416-426.

Hsu CH, Chi BC, Liu MY, et al., (2002): Phosphineinduced oxidative damage in rats: role of glutathione. Toxicology; 179(12):1-8.

Kamel K, Abd El-Raouf OM, Metwally SA, et al., (2014): Hesperidin and Rutin, Antioxidant Citrus Flavonoids, Attenuate Cisplatin-Induced Nephrotoxicity in Rats. J Biochem Molecular toxicology; 28(7): 312-319.

Kaplan A. (1984): Urea. Kaplan. Clinical Chemistry. The C.V Mosby Co. St Louis Toronto Princeton. 12571260.

Kariman H, Heydari K, Fakhri M, et al., (2012): Aluminum phosphide poisoning and oxidative stress: Serum biomarker assessment. J Med Toxicol; 8: 281284.

Küçükler S, Çomaklı S, Özdemir S et al., (2021): Hesperidin protects against the chlorpyrifos-induced chronic hepato-renal toxicity in rats associated with oxidative stress, inflammation, apoptosis, autophagy, and up-regulation of PARP-1/VEGF. Environmental Toxicology; $1-18$.

Luck H. (1972): Catalase. In: Bergmayer, MV Ed. Method of Enzymatic Analysis. Verlag Chemic, Academic Press: New York; 885.

Mahboob M, Shireen KF, Atkinson A, et al., (2001): Lipid peroxidation and antioxidant enzyme activity in different organs of mice exposed to low level of mercury. J. Environ. Sci. Health; 36(5): 687-697.

Mishra HP and Fridovich I (1972): The role of superoxide anion in the autoxidation of epinephrine and a simple assay for superoxide dismutase. J Biol Chem; 247: 3170-3175. 
Moghadamnia AA (2012): An update on toxicology of aluminum phosphide, DARU J. Pharm. Sci; 20-25.

Mokhtar I, Yousef NF, Soliman FM, et al., (2015): Aluminum phosphide-induced hepato-nephrotoxicity and oxidative damage in rats: The protective effect of alpha-lipoic acid. The open conference proceedings journal; (6): 18-23.

Murray RL (1997): Creatinine. Kaplan A. et al. (eds), Clinical Chemistry. The C.V Mosby Co. St Louis Toronto Princeton. 1261-1266.

Nakhaee S, Mehrpour O and Mood M (2017): Does $\mathrm{N}$-acetyl cysteine have protective effects in acute aluminum phosphide poisoning? Indian J Crit Care Med.; 21(8): 144.

Okutucu B, Dinçer A, Habib O, et al., (2007): Comparison of five methods for determination of total plasma protein concentration. J Biochem Biophys Methods 70(5): 709-711.

O’Malley M, Fong H, Sánchez ME, et al., (2013): Inhalation of phosphine gas following a fire associated with fumigation of processed pistachio nuts. J. Agromedicine; 18(2):151-173.

Omar HA, Mohamed WR and Arafa SA (2016): Hesperidin alleviates cisplatin-induced hepatotoxicity in rats without inhibiting its antitumor activity. Pharmacol. Rep; 68: 349-356.

Pari L, Karthikeyan, A, Karthika P, et al., (2015): Protective effects of hesperidin on oxidative stress, dyslipidemia and histological changes in iron-induced hepatic and renal toxicity in rats. Toxicol. Rep; (2): 4655.

Pompella A, Visvikis A, Paolicchi A, et al., (2003): The changing faces of glutathione, a cellular protagonist. Biochem Pharmacol; (66):1499-1503.
Quistad GB, Sparks SE and Casida JE (2000): Chemical model for phosphine induced lipid peroxidation. Pest Manage Sci; 56: 779-783.

Richter CA, Birnbaum LN, Farabollini F et al., (2007): In vivo effects of bisphenol A in laboratory rodent studies. Reproduction Toxicology; 24: 199-224.

Rodilla V, Miles AT, Jenner W, et al., (1998): Exposure of cultured human proximal tubular cells to cadmium, mercury and zinc: toxicity of metallothionein induction. Chem. Biol. Interact.; 115(1): 71-83.

Sales GM and Foresto RD (2020): Drug-induced nephrotoxicity. Rev. Assoc. Med. Bras., 66 (1): 82.

Sembulingam $K$ and Sembulingam $P$ (2010): Essential of Medical Physiology, 5th ed. Jaypee Brother Medical Publisher Ltd.; New Delhi, India.319-321.

Siddiqi A, Nafees S, Rashid S, et al., (2015): Hesperidin ameliorates trichloroethylene-induced nephrotoxicity by abrogation of oxidative stress and apoptosis in wester rats. Mol Cell Biochem; 406: 9-20.

Sudakin DL (2005): Occupational exposure to aluminum phosphide and phosphine gas? A suspected case report and review of the literature. Hum Exp Toxicol; 24 (1): 27-33.

Sweilum OA, Kandeel FS and Noya DA (2017): Management of acute aluminum phosphide toxicity in rat model with novel intervention, atrial of boric acid. Egypt J. Forensic Sci. Appli. Toxicol; 17(12): 57-72.

Tahergorabi Z, Zardasta M, Naghizadeh A, et al., (2020): Effect of aluminum phosphide (ALP) gas inhalation exposure on adipose tissue characteristics and histological toxicity in male rats. Journal of Taibah university for Science; 14 (1): 1317-1325.

\section{التأثير المحسن المحتمل للهسبريدين على التسمح الكلوي الحاد المستحث بواسطة فوسفيد الألمونيوم في البيأي}

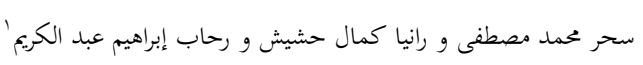

\section{الملخص العربى}

الخلفية العلمية: يعتبر فوسفيد الألمونيوم من الفوسفيد غير العضوي المستخدم في مكافحة الحشرات والقوارض وهو يعتبر شديد السمية

لكل من الإنسان والحيوان ويمكن أن يكون مميتا حتى بكميات قليلة حيث أنه يطلق غازا شديد السمية (الفوسفين) في الظروف الرطبة. يعتبر الهسبريدين وهو جليكوسيد الفلافانون مضاداً للإلتهابات والأكسدة. المدف من البحث:هدفت الدراسة إلى إستكشاف التأثير المحسن المحتمل للهسبريدين المضاد للأكسدة على التغيرات السمية التي يسببها فوسفيد الألومنيوم علي كلى الجرذان البيضاء البالغة بعد التعرض الحاد لفوسفيد الألمونيوم. المواد والطرق: تم تقسيم ستة وثلاثين فأرًا بالغًا من الجرذان البيضاء إلى أربعة مجموعات. المجموعة الأولى

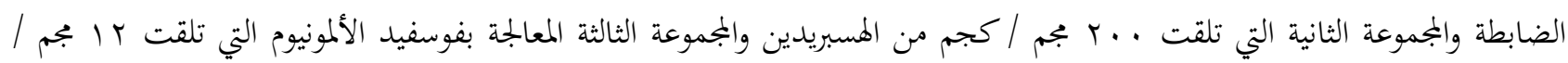
كجم و المجموعة الرابعة المعالجة بالهسبريدين التي تلقت . . ب بجم / كجم من الهسبريدين بعد إعطاء فوسفيد الألمونيوم . تم قياس معدلات البروتين واليوريا والكرياتين ومعدلات الإنزيمات المضادة للأكسدة وعلامات بيروكسيد الدهون وكذلك دراسة التغيرات الهستولوجية بالكلى لئى بإستخدام كل من الميكروسكوب الضوئي والإلكتروني. النتائج: قد أظهرت الدراسة أن إعطاء الهسبريدين العلاجي قد أدى إلى تحسن 
ملحوظ في كل من النتائج البيوكيميائية و نتائج الفحص بالميكروسكوب الضوئي على خلايا الكلى ونتائج الفحص بالميكروسكوب

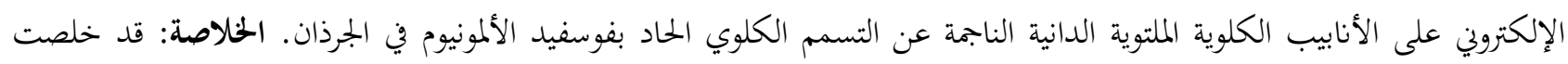

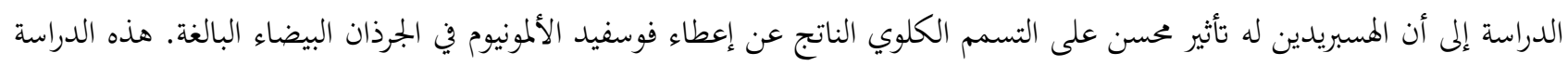

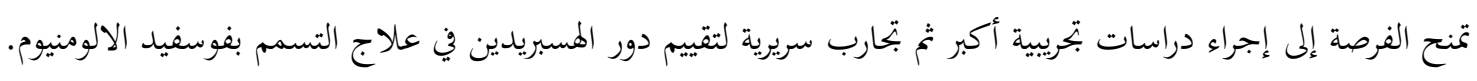

